\title{
ESTUDOS
}

\section{Custos da educação infantil: 0 caso de duas instituições do Distrito Federal*}

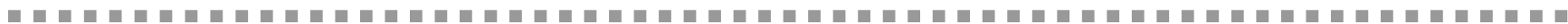
Alberto Merchede

Apresenta os resultados de pesquisa sobre o custo direto de funcionamento de duas instituições de educação infantil situadas, respectivamente, no Plano Piloto de Brasília e numa cidade-satélite do Distrito Federal, sendo uma delas mantida parcialmente pelo poder público e pela comunidade e a outra uma instituição privada (comunitária). Apresenta, também, os custos indiretos para as famílias, calculados com base numa amostra aleatória. A metodologia utilizada baseia-se na metodologia para cálculo do "custo direto de funcionamento das escolas de ensino fundamental", com aplicação inclusive em nível internacional. $O$ resultado é apresentado em termos de custo/aluno/ano e custo/aluno/mês, em parcelas relativas aos itens de custo: pessoal, material de consumo, material permanente, imóvel, outros e custo para as famílias. O estudo compara os resultados das instituições entre si; confronta-os com o perfil de renda dos pais dos alunos e com os preços praticados no mercado pelas instituições privadas de educação infantil e apresenta, a título de exercício, seis situações simuladas. Concluindo, mostra que é possível combinar eficiência e qualidade para atingir os objetivos educacionais.
Palavras-Chave: educação infantil; custos da educação; qualidade do ensino.

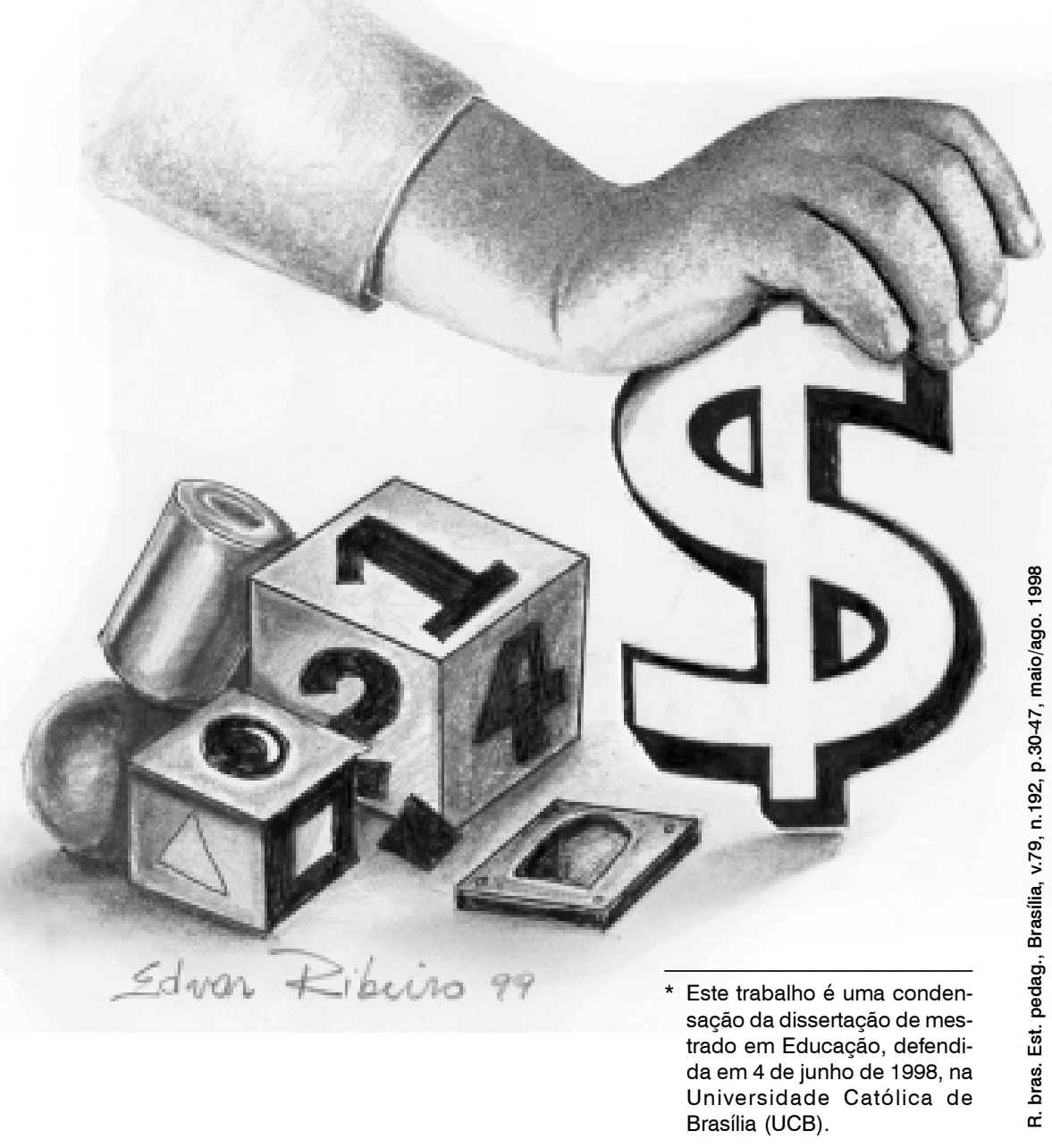




\section{Introdução}

Muitas vezes confundida com gastos, a noção de custos, nas sociedades atuais, está presente no cotidiano. É comum ouvir-se falar em minimização de custos, redução de gastos ou racionalização das despesas. Na verdade, a idéia pode nem sempre estar errada, mas pode estar incompleta. De nada adianta, ou pouco adiantaria reduzirem-se os custos em prejuízo da qualidade. O que se deseja, isso sim, é produzir a mesma coisa de forma mais barata.

Particularmente no caso da educação, a necessidade de se conhecerem os seus custos é de fundamental importância. Entre as utilidades do estudo de custos na educação, Marques (1995, p. 352-355) destaca as seguintes: a) Para o processo de planejamento, em particular na elaboração dos orçamentos. "Não se sabe o que se quer nem por que se quer e muito menos quanto vai custar" (grifo nosso); b) Como

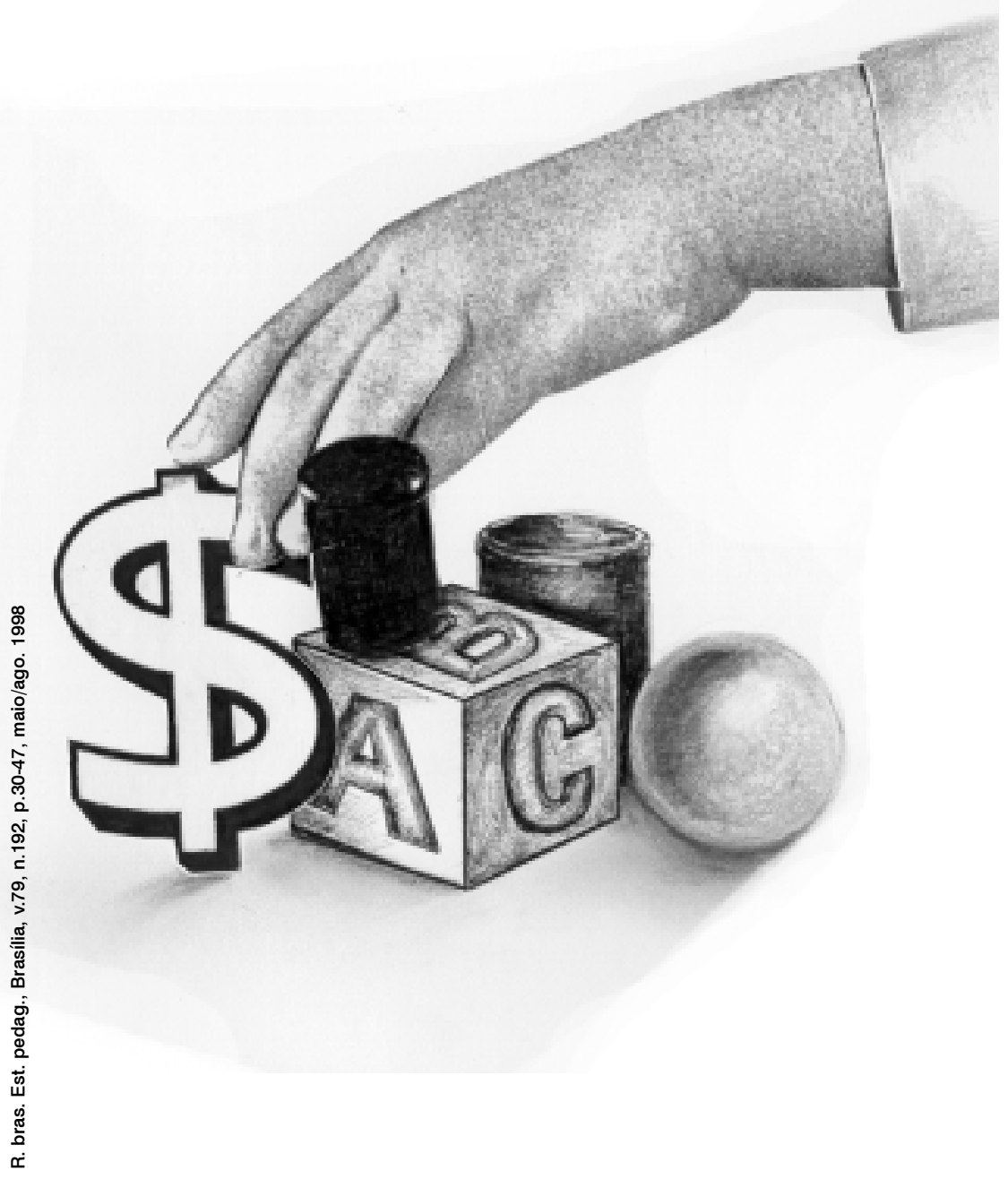

instrumento, para aumentar a visibilidade à frente: quanto vai custar o que estamos fazendo hoje. Para isso, é necessário que se conheçam os custos. Não é suficiente conhecer apenas as despesas.

O objetivo principal do presente trabalho é apresentar o cálculo do custo direto de funcionamento da educação infantil, destinada às crianças de 0 a 6 anos de idade (primeira etapa da Educação Básica), e o custo adicional para os pais, por intermédio de dois estudos de caso, relativamente a duas instituições situadas no Distrito Federal. O custo é calculado por aluno e, em termos de unidade de tempo, por ano (e também por mês), que são as unidades que permitem comparações, ou seja, se prestam com maior facilidade a servir de denominador comum. Os levantamentos foram feitos, portanto, em termos de custo/aluno/ano e custo/aluno/mês, utilizando como referencial o número de alunos matriculados, separadamente na creche e na pré-escola, que são os dois segmentos onde as instituições escolhidas atuam.

O direcionamento do foco de nossos estudos para o primeiro segmento da educação decorre da importância desse segmento no contexto educacional da sociedade e também do fato de não termos informações, diante da literatura consultada, de estudos de custos da educação infantil. São inegáveis os benefícios sociais da educação infantil, incluindo desde a função custodial até aspectos relacionados com a saúde, a alimentação e, sobretudo a educação, não só no que diz respeito à formação de atitudes, mas também como base para o ensino fundamental.

Com relação aos benefícios sociais, vale destacar constatações feitas, por meio de estudo realizado no México (The World Bank, 1993, p. 47), que a educação precoce aumenta as habilidades de desempenho escolar, contribui para que a matrícula escolar ocorra na idade própria, reduz a repetição no primário e, também, melhora o desempenho global acadêmico. Esse impacto benéfico foi verificado em especial entre os grupos tradicionalmente menos favorecidos, tais como meninas e crianças das camadas rurais, indígenas e socioeconômicas inferiores. Ainda segundo a mesma fonte, outro estudo, realizado na Argentina, Bolívia, Chile, Colômbia e Brasil, reforça essa descoberta. Além desses, outro estudo de longo prazo, feito nos 
Estados Unidos, verificou que as crianças com educação infantil precoce têm mais possibilidade de completarem a escola média e é menos provável que sejam beneficiárias de seguro social, que defrontem com problemas legais ou com gravidez na adolescência.

\section{0 financiamento da educação infantil}

Embora a Constituição de 1988 tenha representado significativos avanços e tenha permitido o lançamento de bases para o estabelecimento de políticas educacionais, o princípio constitucional que assegura a educação infantil como direito a que o Estado tem obrigação de atender não foi acompanhado da definição da fonte própria de recursos (Castro, 1994, p. 33). Com efeito, além de a educação infantil não constar como obrigatória ou gratuita, não foram indicadas as origens dos recursos específicos vinculados.

Insere-se nessa abordagem a importante discussão analítica entre os custos econômicos e os custos político-sociais. De um modo geral, todos concordam com que se devam ampliar as ofertas de educação (com qualidade) e destinar-lhes maiores parcelas de recursos. No entanto, quais as ofertas específicas de educação que devem ser maximizadas e quais não devem? Como repartir os recursos disponíveis entre os diversos níveis da educação? O estabelecimento de prioridades políticas, nos moldes utilizados no planejamento político-estratégico, pode constituir-se balizador das dimensões das necessidades de recursos.

Gomes (1994, p. 16) compara com uma arena os processos decisórios sobre recursos financeiros em geral. $\mathrm{O}$ autor menciona em particular os paradigmas político e do processo organizacional para explicar os processos decisórios. Conforme o primeiro paradigma, os atores, localizados em diferentes posições do governo, se envolvem em jogos simultâneos, hierarquicamente superpostos. As decisões e ações emergem desses jogos como resultantes políticas, ou seja, como produtos de compromissos, conflitos, confusões de altos funcionários com interesses e influências desiguais. Já o segundo paradigma, o do processo organizacional, concebe o governo como uma constelação de organizações frouxamente articuladas, em cujo topo se situam os líderes governamentais. Estes têm como critério de escolha as rotinas existentes para as organizações empregarem suas capacidades.

Por outro lado, os governantes, conforme a teoria da escolha pública nos orçamentos, são unidades que visam ao seu próprio bem-estar, com uma agenda diferente daquela da sociedade. Políticos e burocratas procuram maximizar seu próprio bem-estar, mesmo que saibam o que a sociedade prefere. Os grupos de interesse, que com eles interagem, fazem jus ao nome e tratam, antes de tudo, de si próprios (Gallagher, 1993, apud Gomes, 1994, p. 16).

Conforme Gomes e Amaral Sobrinho (1996, p. 11), a depender dos atores e do seu grau de participação política, os critérios e resultados da alocação de recursos serão diferentes. Desse modo, as relações muito assimétricas de poder tornam o setor social menos protegido, precisamente porque as despesas públicas em educação, saúde e saneamento tendem a atender a grupos menos vocais da sociedade.

Segundo Kramer (1993, p. 18), para que o reconhecimento constitucional da obrigação do Estado de oferecer creche se transforme em realidade, é necessário haver legislação e recursos específicos, estabelecidos não só pela LDB, mas também pelas Constituições estaduais. Mesmo assim, a definição legal das fontes de recursos ainda não garante o cumprimento da distribuição. Segundo Castro (1994, p. 34), sabe-se que a vinculação de recursos e sua aplicação exclusiva na educação não têm sido cumpridas com rigor. Por isso mesmo, Romão (1994, p. 70) apresenta-se como grande aliado da educação brasileira neste final de século, no sentido de buscar a reversão desse quadro, o Ministério Público, na medida em que ele exerce seu papel, zelando pelo cumprimento da legislação.

Os dados revelam que, no que concerne ao bem-estar social, a forma de atuação predominante é por meio de convênios estabelecidos entre órgãos públicos e entidades não-governamentais que se constituem meio alternativo de financiamento da educação. Na área da educação préescolar, o recurso a entidades não-governamentais é justificada não só pela neces- 
sidade de baixar custos e buscar maior eficiência, mas também por intermédio de um discurso que valoriza a participação da população (Campos, 1988, p. 19).

No caso das pré-escolas, as redes municipais têm apresentado um expressivo crescimento (Campos et al., 1995, p. 104). Para as autoras, a atuação diversificada e paralela dos órgãos que se ocupam de creches e pré-escolas se refletem na qualidade do atendimento. Quando vinculadas ao sistema regular de ensino, há maior garantia quanto a uma qualificação mínima do pessoal, o que não ocorre com a maioria das creches conveniadas com órgãos de bem-estar. Nessas, a ênfase costuma focalizar a segurança, a higiene e a alimentação.

Por outro lado, mecanismos de repasse de recursos públicos para entidades filantrópicas ou comunitárias têm ensejado a instalação de inúmeras redes de atendimento, que se cruzam nas várias instâncias governamentais. Afirmam as autoras, com base em diagnósticos, que esse paralelismo tem provocado desperdício de recursos.

Todas as dificuldades de busca de fontes alternativas de financiamento para a educação infantil, de aparelhamento das creches e pré-escolas e outras, associadas, no caso das instituições comunitárias de algumas metrópoles, apontam para a necessidade de definição de critérios mínimos, em nível nacional aplicáveis à constituição, equipamento e funcionamento de creches e pré-escolas. Defende-se a manutenção dos convênios sob o argumento de que as entidades privadas conseguem oferecer os mesmos serviços que a rede pública, com custos muito mais baixos. Seria interessante que isso fosse pesquisado, considerando os custos das respectivas máquinas burocráticas (idem, p. 121-123).

Não se poderia encerrar esta análise sem uma referência às famílias como fonte de financiamento. Geralmente incluídas na comunidade, encontram-se raras pesquisas sobre sua participação no custo total. Por analogia, porém, a participação familiar na cobertura dos custos do ensino primário era relativamente elevada. Já em 1968, segundo estudo realizado com relação ao ensino público na Guanabara (Ávila, Cunha, apud Cunha, 1975, p. 146), $55 \%$ dos custos diretos do então ensino primário eram cobertos pelo Estado. Os
$45 \%$ restantes cabiam às famílias dos alunos, incluindo material didático, aulas particulares, contribuição para a caixa escolar, transporte, alimentação, uniformes, etc. A parcela de $45 \%$ dos custos era de $\mathrm{Cr} \$ 137,08$ anuais (em 1968), superando o valor do salário mínimo vigente (Cr\$129,60).

Diante disso, os autores concluem que, dado o padrão de vida presumível das famílias que auferem renda em torno do salário mínimo e dado o número geralmente elevado de filhos, pode-se inferir que a parcela do custo direto que lhes cabe é bastante elevada. Convém esclarecer que os autores conceituam como custos diretos (representados pelos referidos $55 \%$ ) o custeio do ensino propriamente dito, desde a compra do lápis até o pagamento de anuidades.

\section{Custos}

Conforme foi dito no início, custos e despesas são usualmente empregados como expressões sinônimas, mas, dependendo da ótica do campo de estudos em que estejam inseridos, os significados divergem substancialmente. Custo, em sentido genérico, é o esforço (que consome energia física ou mental) ou o dispêndio de bens materiais para se obter alguma coisa. O produto pode ser uma obra intelectual (política, literária ou técnica) ou um bem material (que exige trabalho físico, trabalho mental e consumo de outros bens) ou, ainda, uma satisfação física ou espiritual. Quando o custo envolve valor econômico, pode ser medido pelo preço (Franco, 1987, p. 74). Segundo Holanda (1975, p. 225), os custos são considerados como todo e "qualquer sacrifício feito para produzir um determinado bem, desde que se possa atribuir um valor monetário a esse sacrifício". Correspondem não necessariamente a pagamentos, mas a compensações que devem ser atribuídas aos proprietários dos fatores de produção, devendo algumas vezes ser imputados por não envolverem desembolsos efetivos. Vistos pela ótica da contabilidade, gastos e despesas são usualmente apresentados como sinônimos de custos. Para a economia, "o conceito de despesa se confunde com o de desembolso e nem todo custo se opera mediante saída de dinheiro" (Marques, 1995, p. 355). Visto pelo ângulo da economia, custo sempre significa renúncia a 
uma alternativa como resultado de uma ação ou decisão. Por isso, os economistas freqüentemente usam o termo "custo de oportunidade" ou "custo alternativo" em vez de apenas "custo".

Os custos podem ser definidos - de acordo com o contexto onde vão ser utilizados ou a forma como são apurados em relação ao horizonte temporal (custo/ hora, custo/ano, etc.); à ótica contextual (sob o ângulo da economia, da contabilidade, da educação, etc.); à forma de agregação dos componentes (custo fixo, custo variável, etc.); à agregação do produto (custo/curso, custo/escola, etc.) e assim por diante.

Segundo Castro (1972, p. 32), o critério de demarcação possivelmente mais importante é dado pela distinção entre custo privado e social. Em geral, o custo privado está mais próximo daquele que fornece a contabilidade do que o custo social, embora, segundo o mesmo autor, haja divergências importantes, como, por exemplo, o shadow-rent ("aluguel-sombra") do capital, adiante examinado, que geralmente não é incluído nos custos contábeis. Inclui-se também como custo privado o desembolso ou aumento de despesa da família que manda um de seus membros à escola (Castro,1973, p. 27; Minas Gerais, 1978, p. 17). Já os custos sociais correspondem à idéia de acréscimo às despesas da sociedade. Teoricamente, deveriam referir-se às despesas adicionais da sociedade decorrentes do processo de educação de um indivíduo: "Os custos sociais englobam os insumos para os quais haveria usos alternativos, no caso de a sociedade não destiná-los à educação" (Minas Gerais, 1978, p. 17).

Para Castro (1972, p. 32), possivelmente a visão mais clara de custo social é dada pela idéia de custo de oportunidade, que é praticamente a mesma coisa. Segundo o autor, implica custo para a sociedade tudo aquilo que tem uso alternativo, isto é, tudo aquilo que poderia estar tendo outra aplicação considerada. A avaliação dos custos, segundo a idéia de custo de oportunidade, seria dada pelo seu "valor" no uso alternativo. Custo de oportunidade é a renda sacrificada, a renda que o estudante sacrificou para poder estudar (Marques, 1995, p. 356), ou seja, a renda dos indivíduos que optaram por empregar seu tempo útil no estudo.
O conceito de "preço-sombra" (shadow-price) parece mais interessante na quantificação dos custos. Numa visão mais abrangente, o "preço-sombra", segundo Mishan (1976, p. 109-110), é "aquele que o economista atribui a um bem ou fator com base no argumento de que ele é o mais apropriado para a finalidade do cálculo econômico do que o seu preço vigente, se houver". Na avaliação de um projeto, o economista "corrige" certo número de preços de mercado e, da mesma forma, atribui preços a ganhos e perdas que não têm preços e que se espera que o esquema produza. Pode adicionar algo ao custo de um fator, ou subtrair do custo de um bem, ao considerar alguma deseconomia externa.

A abordagem mais restrita de "preço-sombra", de acordo com Castro (1972, p. 33), é mais adequado às finalidades deste trabalho. Segundo o autor, "preçosombra" é definido como "aquele que prevaleceria se o bem ou serviço fosse produzido e vendido em um mercado de concorrência perfeita no equilíbrio de longo prazo". Em tal mercado, os fatores seriam remunerados de acordo com a sua produtividade marginal, ou seja, os produtos seriam vendidos pelo preço de equilíbrio e os lucros seriam "normais": "O cálculo do "preço-sombra" consiste na simulação destes preços de concorrência que são, em última análise, os custos sociais".

Um aspecto de fundamental importância num estudo de custos, ou seja, num estudo que visa a "definir e avaliar a medida do esforço financeiro desenvolvido para a consecução dos objetivos educacionais", é estabelecer a unidade de análise dessa medida, que é o custo unitário. Em outro enfoque abrangente, "custo unitário de um bem ou de um serviço representa a relação entre o custo de certa quantidade do bem ou serviço e essa quantidade expressa em número de unidades" (Vaizey, Chesswas, 1967, apud Minas Gerais, 1978, p. 19). Ao se examinarem os custos segundo as unidades do produto educacional, tem-se implícita a noção de quantidade desse produto que pode ser representada pelo número de alunos matriculados. Por outro lado, tendo presente que o custo educacional, segundo Castro (1980, p. 52), é uma noção de fluxo e, por conseguinte, tem de ser definido em sua dimensão temporal, naturalmente referindo-se ao intervalo 
de tempo no qual se mede o fluxo de dispêndios diretos ou imputados. Em uma escola que funcione continuamente, tanto faz que os custos sejam medidos em termos de horas, semanas, meses, anos ou cursos. A conversão entre unidades de tempo pode ser facilmente obtida. Entretanto, há unidades de tempo mais convenientes do que outras. "A experiência de trabalho na área sugere que o ano e a hora são as unidades mais adequadas para quase todos os casos" Castro (1980, p. 52). No presente estudo serão apresentados custo/ano, com a vantagem adicional de que os orçamentos também são feitos com base anual e custo/mês, para facilitar comparações em que se utilize tal periodicidade.

Outras categorias de custos também muito importantes são os custos diretos e indiretos e fixos e variáveis. Custos diretos, segundo Franco (1987, p. 137), são aqueles que podem ser apropriados diretamente em relação a cada unidade do produto fabricado e os custos indiretos só podem ser apropriados de forma indireta, por meio de critérios específicos. Enfocando de acordo com as especificidades educacionais, Marques (1995, p. 356) define custo indireto como "aqueles que para serem divididos ou apropriados às diferentes unidades de produção dependem de rateios, estimativas e cálculos" (Zymelman, 1973, apud Xavier, Marques, 1986 , p. 12). Nele se incluem os custos administrativos correspondentes à administração central do sistema educacional, que vão desde a esfera federal até o funcionário menos graduado lotado num estabelecimento de ensino. Os custos que ocorrem dentro da escola podem ser classificados em diretos e indiretos. Os diretos também são chamados custos de produção. Referem-se diretamente ao processo ensino-aprendizagem e ocorrem, quase exclusivamente, na sala de aula. São aqueles que podem ser atribuídos diretamente ao aluno. Já os custos indiretos, também chamados de custos de administração, referem-se aos ocorridos dentro da escola, mas fora da sala de aula.

Quanto aos custos fixos, tecnicamente são aqueles que não variam com a produção, ou seja, são aqueles que, dentro da unidade de tempo considerada, assumem determinado valor independentemente de, nesse mesmo tempo, a empre- sa ter um nível maior ou menor de atividade. São os honorários da administração, os aluguéis, os arrendamentos mercantis, os salários e encargos dos funcionários administrativos. Custos variáveis são aqueles que variam de acordo com o volume de atividade, ou seja, aqueles que, dentro da unidade de tempo considerada, têm o seu valor total determinado exatamente como decorrência do nível de atividade da empresa. São as comissões dos vendedores, consumo de matéria-prima, de embalagens e de outros materiais de uso direto na produção, cujo total do custo (consumo ou utilização no processo de fabricação) depende diretamente do nível de produção (Martins, 1986, p. 176; Leone, 1983, p. 303304).

Segundo Marques (1995, p. 356), para o administrador essa noção de fixo e variável é muito mais importante do que a de custo direto e indireto. O salário do diretor é um custo fixo. De um a 300 alunos, por exemplo, pode permanecer o mesmo. O custo com o servente também o é: de um a 100 alunos pode permanecer o mesmo. Já a merenda escolar é, tipicamente, um custo variável, pois é diretamente proporcional ao número de alunos atendidos. As carteiras também são custo fixo. O conhecimento dos custos fixos é bastante importante para se tomar decisão. Seria insano manter duas escolas, uma ao lado da outra, funcionando com metade de sua capacidade, pois, reunindo todos os alunos em uma única, economizar-se-iam um prédio, um diretor, carteiras, etc.

Os custos também podem ser classificados quanto à abrangência temporal em: custo de planejamento, custo de implantação e custo de funcionamento. Os custos de planejamento compreendem aqueles relativos a despesas realizadas ou custos de oportunidade incorridos desde a concepção da idéia de se reivindicar a construção da escola, como as despesas de transporte dos interessados e a renda sacrificada ao abandonar as atividades que se estejam executando para tratar do assunto (isso para todos os envolvidos no processo: comunidade, prefeito, autoridades, burocratas, etc.). O custo de planejamento ocorre no tempo que transcorre desde a primeira demanda até o início da obra. A partir daí, até a inauguração, ocorrem os custos de implantação. Do início do funcionamento em diante, ocorrem os custos de funcionamento (idem, p. 359-360). 


\section{Metodologia}

\section{Caracterização do estudo e critérios de escolha das instituições pesquisadas}

O presente estudo caracteriza-se como estudo de caso que, segundo Cervo e Bervian (1996, p. 49), é uma das formas da pesquisa descritiva. Para os autores, a pesquisa descritiva é aquela que observa, registra, analisa e correlaciona fatos ou fenômenos (variáveis), sem manipulá-los. A escolha das instituições que constituíram objeto deste estudo obedeceu aos três seguintes critérios: a) diversificação geográfica (uma no Plano Piloto de Brasília e outra numa cidade-satélite do Distrito Federal); b) diversificação de status socioeconômico das crianças e c) possibilidade de acesso aos dados. Após escolhidas as localizações que atendessem aos dois primeiros critérios, buscou-se, por meio de contatos com pessoas da área, identificar duas instituições em que fosse possível coletar os dados. Em face desses critérios, as instituições escoIhidas não representam o todo. A primeira das instituições escolhidas é localizada no Plano Piloto de Brasília e aqui a trataremos por Instituição no 1, enquanto a Instituição no 2 fica numa cidade-satélite do Distrito Federal. Descrição mais pormenorizada de ambas estará exposta adiante.

\section{Procedimentos metodológicos}

Para obtenção dos dados e informações, foram aplicados os seguintes instrumentos: a) questionário de levantamento de custos, organizado para coletar além dos dados de custos (mão-de-obra, material de consumo, material permanente, serviços de terceiros e outras despesas), também dados identificadores das Instituições, área dos prédios e dos terrenos; b) roteiro de entrevistas com os pais, a direção e os secretários; c) roteiro de análise das fichas de inscrição das crianças; d) roteiro básico de observação; e) roteiro de levantamento de preços praticados por instituições privadas de educação infantil no Distrito Federal.

A metodologia de cálculo adotada foi baseada no estudo "Custo direto de funcionamento das escolas de 1 grau", de
Xavier e Marques (1986), já testada e aplicada em outros países. Para o presente estudo, houve uma ampliação, de modo a contemplar o custo dos serviços do capital e as despesas adicionais para os pais dos alunos.

Os itens de custo considerados foram os seguintes: custo direto da mão-de-obra; custo do material de consumo; custo do material permanente; custos com serviços de terceiros; outras despesas; custos dos serviços de capital e custos com que arcam as famílias (despesas de intervenção). Os dados relativos aos cinco primeiros itens foram obtidos mediante análise documental, levantamento de dados e entrevistas com diretor e secretária das instituições. Os procedimentos foram os seguintes:

a) Custo direto da mão-de-obra Compreende o custo com pessoal docente e não docente. Inclui remuneração dos professores, técnicos e pessoal administrativo de modo geral. Além da remuneração, foram considerados os encargos pertinentes com que a organização arca (trabalhistas, previdenciários e sociais). Os procedimentos adotados para os cálculos foram os seguintes: primeiramente foi apurada a renda bruta mensal do pessoal docente, separada por nível (creche e préescola), e do pessoal não-docente. A seguir foi calculada a remuneração bruta anual, mediante multiplicação dos valores mensais por $141 / 3$ (=12 salários anuais + décimo terceiro + férias $+1 / 3$ ). Os encargos trabalhistas e previdenciários foram calculados mediante aplicação de percentuais específicos, de acordo com o regime de vinculação - Regime Jurídico Único ou Consolidação das Leis do Trabalho (CLT). Além desses, foram apurados outros encargos anuais relativos à mão-deobra, designados por "demais encargos" (como vale-transporte, por exemplo). A soma desses três itens (salário bruto, encargos trabalhistas e previdenciários e demais encargos) representa o custo bruto anual da mão-de-obra. No caso da Instituição $\mathrm{n}$ - 1 , que atende aos dois níveis de educação infantil (creche e pré-escola), o custo do pessoal não-docente bem como os demais itens de custo (material de consumo, material permanente, etc.) foram divididos em duas partes proporcionais, respectivamente, ao custo do pessoal docente da creche e da pré-escola. No caso da Instituição no 2 , bastou somar 
os custos do pessoal docente e não-docente, já que se referem a um único nível de educação.

b) Custo do material de consumo Refere-se aos bens necessários à manutenção dos serviços ou a seu apoio e que são teoricamente consumidos num período inferior a dois anos. Inclui material de cantina, didático, de enfermaria, esportivo, de limpeza, etc. Os valores foram obtidos por meio de levantamento da quantidade consumida anualmente (a maioria por escrituração e alguns raros por estimativa), aplicando-se-Ihes os preços de mercado, obtidos por meio de pesquisa feita no mês de outubro de 1997, época da coleta de dados como um todo. Para cada item, foram coletados preços em, no mínimo, duas fontes, optando-se, sempre, quando da consolidação dos dados, pelos de menor valor.

c) Custo do material permanente - São os custos relacionados com os equipamentos e materiais com vida útil teoricamente igual ou superior a dois anos, como, por exemplo, mesas, cadeiras, impressoras, microcomputadores, etc. Esses custos constituem os custos dos serviços do capital, que diferem do valor do capital. Este último compreende o custo da escola, do terreno, dos equipamentos. Já o custo dos serviços do capital refere-se à imputação que se faz para a utilização anual da escola, do terreno e dos equipamentos. Diferentemente da matéria-prima que é consumida no ciclo produtivo, o capital entra e sai do ciclo produtivo, exibindo a característica de permanência. Podem-se considerar três categorias de custos de capital, a saber: custo de manutenção (média histórica), custo de oportunidade (taxa de desconto ou taxa de rentabilidade social do capital) e depreciação (Rio de Janeiro, s.d, p. 9-12) ou, alternativamente, utiliza-se o shadow-rent, que "corresponde ao aluguel que seria cobrado em um mercado de concorrência perfeita" (Castro,1972, p. 46).

No presente estudo, os procedimentos para cálculo dos custos de reposição referentes ao material permanente foram os seguintes: após levantamento de todos os materiais, foram-Ihes aplicados os preços de reposição, obtidos por intermédio de pesquisa de mercado feita em outubro de 1997 (considerandose sempre o menor preço pesquisado) e foi também estabelecida a vida útil de cada um. $O$ custo anual de cada item (ou seja, a porcentagem anual de desgaste) foi obtido dividindo-se o preço pela vida útil (em anos). A estimativa de vida foi baseada, na maioria dos itens do material permanente, no estudo de custo direto de funcionamento em cuja metodologia o presente estudo se baseou (Xavier, Marques, 1986).

d) Outras despesas - Trata-se de despesas não classificadas nos itens anteriores e/ou que se deseja destacar. Foram, por exemplo, as despesas com energia, gás, telefone, água e esgoto e outras. Salvo alguns itens, cujos valores foram estimados, na maioria dos casos, os valores foram obtidos nos registros das instituições estudadas.

e) Custos com serviços de terceiros Decorrem da prestação de serviços a cargo de empresas especializadas ou de pessoas não lotadas na escola, bem como as despesas não classificadas anteriormente. Todos os valores foram obtidos nos registros das instituições pesquisadas.

Custos dos serviços de capital (edifícios e terrenos) - Optou-se pelo uso do shadow-rent. Estão representados por estimativa do aluguel dos imóveis, fornecida informalmente por profissional da área.

Os custos com que arcam as famílias (despesas de intervenção) compreendem as despesas adicionais com que as famílias arcam para manterem os filhos na creche ou pré-escola, como, por exemplo, transporte, uniforme, calçados e outras. Os valores foram obtidos através de pesquisa em amostra de $10 \%$ dos alunos. O sorteio foi feito atribuindo-se numeração única seqüencial aos alunos (de 1 até, por exemplo, 100) e colocando-se bilhetes, contendo os números, em um depósito. Cada número sorteado ia voltando para dentro do depósito, de modo que não fosse alterada a probabilidade individual (1/100).

Ao final, para obtenção do custo/aluno/ano, dividiu-se o custo total (o somatório de todos os custos) pelo número de alunos. Para obtenção do custo/aluno/mês, dividiu-se o custo/aluno/ano por 12. Esses custos foram segmentados nos itens constitutivos, tais como: mão-de-obra, material de consumo, material permanente, despesas com serviços de terceiros, outras despesas, shadow-rent do imóvel e despesas com que arcam as famílias e, no caso da Instituição $n$ ㅇ 1, desmembrados em creche e pré-escola. 


\section{Análise dos resultados}

\section{Características das instituições estudadas}

\begin{abstract}
A Instituição no 1 atende a 100 crianças de 0 a 6 anos, sendo 80 na creche (horário integral, das $8 \mathrm{~h}$ às $18 \mathrm{~h}$, perfazendo 10 horas) e 20 na pré-escola (meio período, das $8 \mathrm{~h}$ às $12 \mathrm{~h} 30$, totalizando $4 \mathrm{~h} 30$ ). E mantida em parceria entre o Governo $\mathrm{Fe}$ deral, o Governo do Distrito Federal (GDF) e a Associação de Pais e Mestres (APM). Foi criada na esfera federal, para atender aos filhos de funcionários de um ministério que foi extinto. Com essa extinção, o pessoal remanescente continuou na folha do governo federal e o acervo patrimonial foi transferido ao GDF, a quem cabe a administração e arca com as despesas de manutenção (água, energia, telefone, etc.), inclusive do pessoal a seu cargo. As demais despesas complementares, entre elas também pessoal, são custeadas pela APM, cujos recursos provêm de contribuições. Aproximadamente $60 \%$ dos pais contribuem com o "auxílio creche" de $\mathrm{R} \$ \mathbf{8 5 , 0 0}$ mensais que recebem em seus contracheques. Os demais contribuem com qualquer importância ( $R$ \$10,00; $R \$ 20,00)$ e alguns
\end{abstract} não contribuem.

A instituição conta com 53 funcionários, dos quais 27 são docentes. Estão assim distribuídos: 13 a cargo do GDF; 29 do governo federal e 11 da APM. Quanto à formação, somente a diretora e a secretária possuem curso superior. Do pessoal docente, que compreende professores e auxiliares, os primeiros, cujo provimento é feito pelo GDF, todos, possuem formação em magistério, em nível médio. Alguns cursam faculdade nas áreas de pedagogia e psicologia. Dos auxiliares, todos provindos do ministério ao qual pertencia a Instituição, alguns concluíram o ensino fundamental; outros estão cursando o ensino médio. Os demais funcionários encontram-se em situação semelhante a dos auxiliares. Com relação ao perfil salarial (salário bruto mensal) do pessoal docente, a média é de 5,9 salários mínimos e o maior salário é de 7,5. Isso para a creche. Para a pré-escola, os salários são todos iguais, situando-se em 7,5 salários mínimos. Quanto ao pessoal docente, a média é de 4,7 salários mínimos e o maior salário bruto é de 17,5 salários mínimos.
O terreno ocupado pela instituição mede em torno de $15.000 \mathrm{~m}^{2}$ e a área construída por ela utilizada mede aproximadamente $1.120 \mathrm{~m}^{2}$. Há ao todo $48 \mathrm{com}$ partimentos (inclusive banheiros), dos quais nove são salas de aula. Pode-se observar a existência de muito espaço destinado a atividades-meio e pouco para as atividades-fim. Esse desequilíbrio contribui para onerar os custos. As instalações, pelo bom estado de conservação e limpeza, aparentam estar sendo objeto de constantes cuidados e manutenção. Os móveis denotam requinte. São poltronas em couro trabalhado, sofás e mesas de centro de madeira com detalhes de couro, etc.

A Instituição funciona de segunda-feira a sexta-feira, das $7 \mathrm{~h} 30$ às $19 \mathrm{~h}$, sendo que a pré-escola funciona apenas no horário matinal, das $7 \mathrm{~h} 30$ às $13 \mathrm{~h}$. Esses são horários de funcionamento da Instituição, aos quais se circunscreve o horário de atendimento às crianças.

Quanto à Instituição no 2, atende a 90 crianças na faixa de 4 meses a 3 anos de idade, todas na creche e em horário integral, das $7 \mathrm{~h}$ às $19 \mathrm{~h}$. Foi construída pela Associação de Moradores da Quadra, com ajuda do governo do Distrito Federal e da Associação de Moradores da Cidade-Satélite e embora seja formalmente denominada "Creche Comunitária", sobrevive através de doações e de um convênio firmado com a Fundação do Serviço Social. A Fundação contribui em média com $\mathrm{R} \$ 8$ mil (desse repasse, 65\% devem ser gastos com pessoal). As despesas mensais situam-se em torno dos $\mathrm{R} \$ 10 \mathrm{mil}$. A complementação do pagamento é obtida por intermédio de ajuda da comunidade $e$ em alguns casos, da Administração Regional da cidade-satélite. A creche é totalmente gratuita para as famílias, que são constituídas por pessoas de baixa renda. A inconstância e a incerteza quanto ao recebimento dos recursos públicos complementares têm acarretado freqüentes atrasos nos pagamentos de contas de energia, telefone e outras despesas. Na verdade, a parcela de contribuição a cargo da comunidade tem-se limitado ao fornecimento de material de consumo (alimentos, material de limpeza e algum material escolar).

A Instituição no 2 conta com 24 funcionários, dos quais 16 são docentes. $O$ cargo de diretor não é remunerado. Seu ocupante, que o acumula com o cargo de pre- 
sidente da associação de moradores, também dirige negócios próprios, o que lhe acarreta sobrecarga de afazeres. Por isso, parte significativa das tarefas inerentes à direção da Instituição no 2 é exercida pela secretária, que, além das atividades próprias da secretaria, exerce as de gestão do pessoal; controle do estoque de material (almoxarifado) e compras. Para efeito de apuração de custos, foi imputada, para o diretor, uma carga horária de 20 horas semanais, incluindo tanto as tarefas exercidas interna como externamente. A estimativa do valor foi feita com base proporcional à remuneração do diretor da Instituição no 1 .

Quanto à formação, apenas o diretor possui curso superior. A secretária concluiu o ensino médio (supletivo). Dos docentes, alguns concluíram o ensino médio e outros o estão cursando. Dos que concluíram, apenas um elemento possui formação em magistério. Os que estão cursando o ensino médio optaram pelas áreas de contabilidade, administração, etc. Nenhum pela área do magistério. Os demais funcionários encontramse em nível de ensino fundamental. Uns completaram-no; outros, não. Como se pode observar, é visível a debilidade do ponto de vista técnico-pedagógico. Com relação ao perfil salarial, todos os docentes auferem, como salário bruto, 1,5 salários mínimos, mas com o pessoal nãodocente a média é de 2,6 e o maior salário bruto é de 8,8 salários mínimos.

O imóvel onde funciona a instituição é constituído por bloco único, medindo
$247 \mathrm{~m}^{2}$ de área construída, em terreno de $1.382 \mathrm{~m}^{2}$. Há ao todo 12 compartimentos (incluindo banheiros), dos quais quatro são salas de aula.

\section{Custo médio da educação infantil}

As Tabelas 1, 2 e 3 contêm os resultados dos custos médios das instituições estudadas, relativamente aos seguintes itens: pessoal, material de consumo, material permanente, despesas com serviços de terceiros, outras despesas e shadow-rent do imóvel. Além disso, é apresentado o gasto médio dos pais para manterem as crianças na escola. Este último item foi obtido a partir de pesquisa feita junto às famílias de $10 \%$ dos alunos (Tabela 1).

A existência de proporcionalidade entre os itens das Tabelas 1 e 2 decorre do fato de seu desdobramento (em creche e pré-escola) ter sido calculado proporcionalmente aos custos do pessoal docente, conforme descrito na metodologia. Por isso, a participação percentual, por exemplo, do custo de pessoal, com relação ao total, é sempre a mesma nas duas tabelas. Podese notar, nas três tabelas, que o componente mais expressivo é o custo do pessoal. Aliás, até mesmo cada um de seus dois subitens ("Docentes" e "Não-docentes"), isoladamente, é superior a qualquer um dos demais itens de custo. Considerando os custos totais, o componente custo do pessoal como um todo (soma dos dois subitens que o compõem) representa quase $70 \%$ desse total. Excluindo-se os itens shadow-

\section{Tabela 1 - Instituição no 1: Resultado do cálculo dos custos da educação infantil na creche}

Valores correntes de outubro/97 em R\$

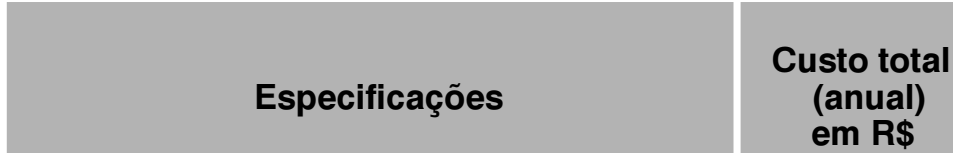

1.1. Custo do pessoal

Docente

Não-Docente

1.2. Custo do material de consumo

de reposição do material permanente $19.007,36$

1.4. Despesas com serviços de terceiros

1.5. Outras despesas

Subtotal

1.6. Shadow-rent do imóvel

1.7. Despesas da família

Total

$2.585,66$

$42.924,19$

$327.087,00$

$252.450,05$

$28.192,74$

$672.247,00$

$152.954,58$

$4.206,25$

$829.407,84$
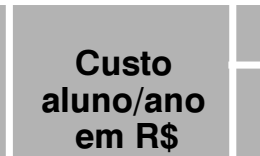

Custo aluno/mês

\begin{tabular}{c|c|c|} 
R\$ sobre & $\begin{array}{c}\text { \% sobre } \\
\text { o Total }\end{array}$ & o Subtotal
\end{tabular}

$\begin{array}{rrrr}4.088,59 & 340,72 & 39,4 & 48,7 \\ 3.155,63 & 262,97 & 30,4 & 37,6 \\ 352,41 & 29,37 & 3,4 & 4,2 \\ 237,59 & 19,80 & 2,3 & 2,8 \\ 32,32 & 2,69 & 0,3 & 0,4 \\ 536,55 & 44,71 & 5,2 & 6,4\end{array}$

$\begin{array}{llll}\mathbf{8 . 4 0 3 , 0 9} & \mathbf{7 0 0 , 2 6} & \mathbf{8 1 , 0} & \mathbf{1 0 0 , 0}\end{array}$

$2.048,50 \quad 159,33 \quad 18,4$

52,58

4,38

0,5

$10.367,60 \quad 863,97 \quad 100,0$


Tabela 2 - Instituição no 1: Resultado do cálculo dos custos da educação infantil na pré-escola Valores correntes de outubro/97em R\$

\begin{tabular}{|c|c|c|c|c|c|}
\hline \multirow[b]{2}{*}{ Especificações } & \multirow{2}{*}{$\begin{array}{c}\text { Custo total } \\
\text { (anual) } \\
\text { em R\$ }\end{array}$} & \multirow{2}{*}{$\begin{array}{c}\text { Custo } \\
\text { aluno/ano } \\
\text { em R\$ }\end{array}$} & \multicolumn{3}{|c|}{ Custo aluno/mês } \\
\hline & & & $\mathbf{R} \$$ & $\begin{array}{c}\text { \% sobre } \\
\text { o Total }\end{array}$ & $\begin{array}{l}\% \text { sobre } \\
\text { o Subtotal }\end{array}$ \\
\hline \multicolumn{6}{|l|}{ 1.1. Custo do pessoal } \\
\hline Docente & $32.174,00$ & $1.608,70$ & 134,06 & 39,4 & 48,7 \\
\hline Não-Docente & $24.832,32$ & $1.241,62$ & 103,47 & 30,4 & 37,6 \\
\hline 1.2. Custo do material de consumo & $2.773,19$ & 138,66 & 11,55 & 3,4 & 4,2 \\
\hline 1.3. Custo de reposição do material permanente & $1.869,66$ & 93,48 & 7,79 & 2,3 & 2,8 \\
\hline 1.4. Despesas com serviços de terceiros & 254,34 & 12,72 & 1,06 & 0,3 & 0,4 \\
\hline 1.5. Outras despesas & $4.222,25$ & 211,11 & 17,59 & 5,2 & 6,4 \\
\hline Subtotal & $66.125,76$ & $3.306,29$ & 275,52 & 81,0 & 100,0 \\
\hline 1.6. "Shadow-rent" do imóvel & $15.045,42$ & 751,27 & 62,69 & 18,4 & \\
\hline 1.7. Despesas da família & 413,75 & 20,69 & 1,72 & 0,5 & \\
\hline Total & $81.584,92$ & $4.079,25$ & 339,94 & 100,0 & \\
\hline
\end{tabular}

Fonte: Pesquisa de campo realizada pelo autor.

rent do imóvel e despesas da família, a participação dos custos de pessoal sobe para $86,3 \%$, no caso da Instituição no 1 e para $73,2 \%$ no caso da Instituição no 2 (Tabela 2).

Esses patamares de participação da despesa de pessoal aproxima-se do referencial contido no estudo "Custo direto de funcionamento das escolas da rede oficial do Distrito Federal - 1985", realizado pelo GDF (1986, p. 31). Segundo esse estudo, os custos de pessoal situam-se em torno de $90 \%$ dos custos totais. O segundo item mais expressivo, no caso da Instituição no 1 , é o shadow-rent do imóvel, cuja magnitude se explica pela sua área e por situar-se em local valorizado do Distrito Federal.
No caso da Instituição $n$ ㅇ 2, esse item ocupa o terceiro lugar. Em segundo, encontra-se o componente "Custo do material de consumo", cuja posição expressiva pode se explicar por estarem incluídos neste item de custo todos os gastos com alimentação diária tanto das 90 crianças, como dos demais funcionários que trabaIham em horário integral (Tabela 3).

\section{Comparação das instituições estudadas entre si}

Objetivando facilitar a compreensão das entidades, será considerada, da Instituição $\mathrm{n}$ - 1 , apenas a creche, que será comparada com a Instituição no 2 . É de

\section{Tabela 3 - Instituição no 2: Resultado do cálculo dos custos da educação infantil (creche) Valores correntes de outubro/97em R\$}

\begin{tabular}{|c|c|c|c|c|c|}
\hline \multirow[b]{2}{*}{ Especificações } & \multirow{2}{*}{$\begin{array}{c}\text { Custo total } \\
\text { (anual) } \\
\text { em R\$ }\end{array}$} & \multirow{2}{*}{$\begin{array}{c}\text { Custo } \\
\text { aluno/ano } \\
\text { em R\$ }\end{array}$} & \multicolumn{3}{|c|}{ Custo aluno/mês } \\
\hline & & & $\mathbf{R} \$$ & $\begin{array}{c}\text { \% sobre } \\
\text { o Total }\end{array}$ & $\begin{array}{c}\% \text { sobre } \\
\text { o Subtotal }\end{array}$ \\
\hline \multicolumn{6}{|l|}{ 1.1. Custo do pessoal } \\
\hline Docente & $58.667,68$ & 651,86 & 54,32 & 37,5 & 42,0 \\
\hline Não-Docente & $43.547,32$ & 483,86 & 40,32 & 27,8 & 31,2 \\
\hline 1.2. Custo do material de consumo & $24.868,42$ & 276,32 & 23,03 & 15,9 & 17,8 \\
\hline 1.3. Custo de reposição do material permanente & $5.155,72$ & 57,29 & 4,77 & 3,3 & 3,7 \\
\hline 1.4. Despesas com serviços de terceiros & $2.340,00$ & 26,00 & 2,17 & 1,5 & 1,7 \\
\hline 1.5. Outras despesas & $5.206,25$ & 57,85 & 4,82 & 3,3 & 3,7 \\
\hline Subtotal & $139.785,38$ & $1.553,17$ & 129,43 & 89,2 & 100,0 \\
\hline 1.6. Shadow-rent do imóvel & $14.400,00$ & 160,00 & 13,33 & 9,2 & \\
\hline 1.7. Despesas da família & $2.454,00$ & 24,54 & 2,05 & 1,6 & \\
\hline Total & $156.639,38$ & $1.737,71$ & 144,81 & 100,0 & \\
\hline
\end{tabular}


notar que, embora ambas as creches abriguem praticamente o mesmo número de crianças, o custo aluno/mês da primeira mesmo excluindo o aluguel do imóvel (shadow-rent) e as despesas da família ultrapassa o quíntuplo da outra $(\operatorname{R} \$ 700,26$ para $R \$ 129,43)$.

Além dos custos do pessoal, o item que mais se destaca nessa comparação é o valor shadow price do imóvel, que, em termos absolutos, é representado pelas médias mensais por aluno de $R \$ 159,33$ e $R \$ 13,33$, respectivamente. Essa diferença é justificada pela disparidade dos valores dos respectivos imóveis. Conforme mostram os números, a diferença é tão expressiva que o espaço ocupado pela área total construída da primeira é maior do que todo o terreno da Instituição no 2. Além disso, o material utilizado nas respectivas construções revela acentuada diferença de qualidade em favor da creche do Plano Piloto. Quanto ao material permanente, o requinte e a qualidade dos móveis e utensílios da Instituição $\mathrm{n}$ - 1, conforme já foi descrito, fazem com que os custos de reposição do material permanente da creche do Plano Piloto sejam mais de quatro vezes os da outra creche (R\$19,80 para $R \$ 4,77)$, embora em termos de participação percentual, com relação aos respectivos totais, a proporcionalidade seja em sentido inverso, em face de outros itens.

Outro aspecto a ser considerado é a capacidade ociosa da Instituição $\mathrm{n}-1$ que, conforme a direção, teria capacidade para atender em torno de 300 crianças, portanto, o triplo do contingente atual. Isso obviamente se reflete no custo fixo, pois a manutenção do prédio, as despesas com energia e outras têm praticamente a mes- ma dimensão, qualquer que seja a quantidade de alunos.

Além desses fatores, outros também contribuem para essa diferença de custos. $\mathrm{Na}$ Instituição $\mathrm{n} 0$ 1, a relação entre o número de crianças atendidas e o pessoal docente é de 3,8 , enquanto que na Instituição no 2, é de 5,6. Segundo informações da direção da Instituição no1, embora seja quantitativamente elevado o quadro de pessoal herdado do ministério, ele tem sido qualitativamente insuficiente. Do outro lado da comparação, o contingente reduzido da Instituição no 2, conforme já foi abordado, sobrecarrega a secretária, que exerce atividades de diretor, recepcionista, secretária, gerente do pessoal, controladora do almoxarifado, etc.

\section{Perfil de renda dos pais}

Da pesquisa feita junto às famílias dos alunos, com o intuito de confrontar os custos sob estudo com o perfil de renda familiar, foi possível obter dados das famílias de 58 crianças da creche e de $16 \mathrm{da}$ pré-escola, da Instituição $n$ o 1 , além das famílias de 80 crianças da Instituição no 2 .

Com relação às famílias das crianças da creche da Instituição no 1, a renda média é de 13,1, para um custo médio de 7,2 salários mínimos, ou seja, o custo de um aluno/mês eqüivale a $55 \%$ da renda mensal bruta dos pais. Quanto à préescola, a média da renda bruta familiar cai para 9,5 salários mínimos e o custo/ aluno/mês para 2,8 salários mínimos, passando este a representar um terço daquela média. Finalmente, quanto à Instituição № 2, a média da renda familiar bruta é de

\section{Gráfico 1- Comparação entre o perfil de renda das famílias e o custo aluno/mês das instituições estudadas - em salários mínimos - outubro de 1997}

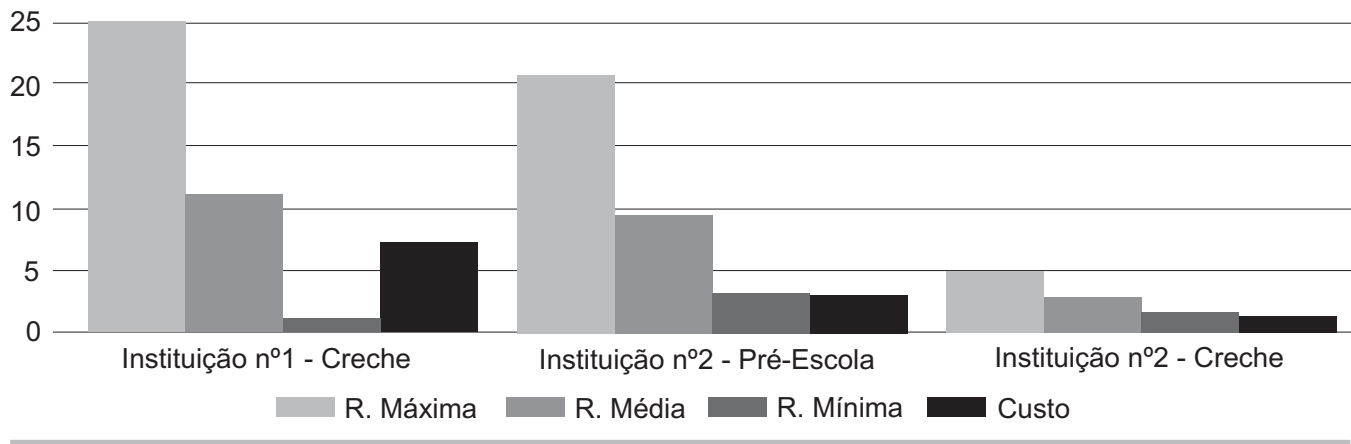

Fonte: Pesquisa de campo realizada pelo autor. 
2,8 salários mínimos, para um custo de 1,2 salários mínimos, representando este menos da metade daquela média. Convém considerar, nessa comparação entre o perfil de renda e o custo médio, que este representa a média mensal, ou seja, o custo anual dividido por 12 , enquanto para estabelecimento do perfil de renda foi tomada a renda bruta mensal (sem os descontos) e não a média.

O Gráfico 1 exibe a comparação entre o perfil de renda das famílias e os custos aqui calculados. Confrontando os dados das duas instituições, constata-se uma significativa diferença entre os níveis de renda, vindo a corroborar a diversidade de status socioeconômico, que foi um dos critérios que nortearam a escolha do objeto da presente pesquisa.

\section{Preços das mensalidades praticados no mercado}

Com o propósito de ampliar a análise para o âmbito do mercado, foram pesquisados os preços praticados por entidades privadas que atuam na educação infantil, tanto no Plano Piloto (em horário integral e parcial), como em duas cidades-satélites com idênticas características (em horário integral), sendo uma delas aquela onde se localiza a Instituição no 2. Algumas das entidades pesquisadas declaram dispor de nutricionista e enfermeira em seus quadros. Outras declaram dispor de médico pediatra que atende regularmente ou, então, que se encontra disponível para emergência. No entanto, esses serviços adicionais não estão relacionados necessariamente com mais alto preço praticado. Com respeito às instituições objeto do presente estudo, esses serviços adicionais inexistem, a não ser quanto à nutricionista, que, segundo informações, realiza visitas esporádicas à Instituição no 1 .

Quanto à duração do período de atendimento, foi constatado que o valor da mensalidade não varia no mesmo sentido do tempo de atendimento. O preço médio mensal praticado pelas entidades que atuam em creches no Plano Piloto é de $\mathrm{R} \$ 506,65$, em valores correntes de outubro de 1997. O maior preço da pesquisa, que é $R \$ 712,00$, é inferior ao custo médio mensal aqui calculado para a creche da Instituição no 1 , que é de $\mathrm{R} \$ 863,97$. O mesmo ocorre com relação à pré-escola, pois os preços médios praticados pelas entidades que atuam no segmento é de $R \$ 275,50$ e o maior preço é $R \$ 331,00$, enquanto que os custos aqui calculados são de $\mathrm{R} \$ 339,94$.

Quanto à Instituição no 2 , a situação é bem diferente. $O$ custo aluno/mês aqui calculado, de R\$144,81, é inferior ao preço médio praticado pelas entidades, que é de $R \$ 271,00$. Aliás, o custo é também inferior ao menor preço, que é de $\mathrm{R} \$ 258,00$. O Gráfico 2 permite visualizar claramente a expressiva magnitude do custo da creche da Instituição no 1 com relação à renda familiar mínima.

\section{Simulações}

A título de exercício, foram feitos seis cálculos simulatórios, designados, para faci-

Gráfico 2 - Comparação entre os preços praticados no mercado e os custos da educação infantil - custo aluno/mês - valores correntes de outubro de $1997 \mathrm{em}$ R\$

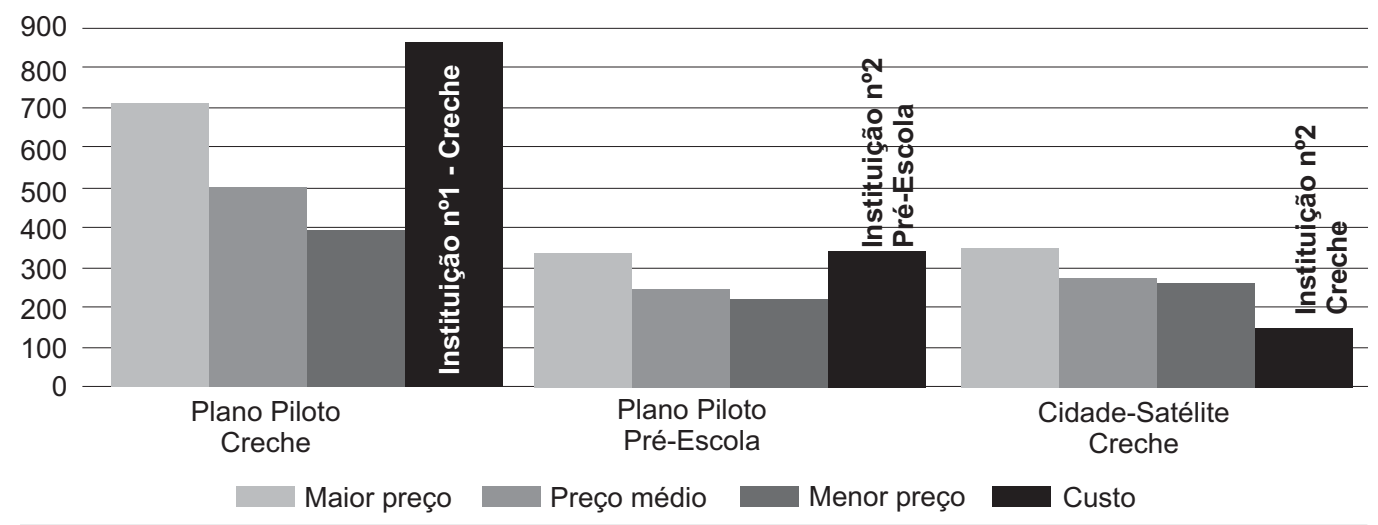

Fonte: Pesquisa de campo realizada pelo autor. 
lidade de referência, como custos simulados $A$, custos simulados $B$, etc., até custos simulados $F$. Os cinco primeiros referem-se à Instituição no 1 e o último, à Instituição no 2. Eis as características de cada exercício de simulação:

a) Custos simulados A: obtidos mediante a exclusão de um excedente de mão-de-obra estimado pela direção em torno de sete funcionários (sendo seis nas salas de aula e um funcionário não-docente). Segundo a direção, esse seria o excedente máximo possível de que se poderia abrir mão sem perda da qualidade do atendimento.

b) Custos simulados B: parte-se da hipótese de utilização plena da capacidade estimada, para contemplar a ampliação do atendimento para 300 crianças, todas na creche (em dois turnos).

c) Custos simulados C: resultam, igualmente, da hipótese de ampliação do atendimento para 300 crianças. Neste caso, todas na pré-escola (em um turno).

d) Custos simulados $D$ : dizem respeito à hipótese de ampliação da clientela para 600 crianças, todas na pré-escola, sendo metade em cada turno.

e) Custos simulados E: resultam da hipótese de ampliação do contingente para 300 crianças, sendo metade na creche (horário integral) e metade na préescola (um turno);

f) Custos simulados F: compreendem a hipótese de ampliação do quadro de nãodocentes da Instituição no 2, mediante inclusão de um coordenador ou gestor, com vistas a contemplar a possibilidade de reforçar-se a dotação em nível gerencial.
Em todos os exercícios relativos à Instituição no 1 , os itens "Despesas com serviços de terceiros", "shadow-rent do imóvel" e "Despesas da família" foram mantidos inalterados. Com relação ao material permanente, onde se observou existência de ociosidade, foi admitido um acréscimo de apenas $10 \%$, destinado a complementar os móveis das novas salas a serem ocupadas, bem como outros possíveis materiais de refeitório. Esse procedimento não contemplou a primeira simulação, antes descrita.

No caso do exercício simulatório relativo à Instituição no 2 , tratado como custos simulados $F$, resultante da hipótese de ampliação do quadro de não-docentes, a remuneração do cargo ampliado (gerente ou coordenador) foi estimada em três quartos do salário mensal do diretor da Instituição no 1 . Além disso, o exercício simulatório prevê uma redução da carga horária imputada ao atual diretor da Instituição $n$ ㅇ 2, que passaria de 20 horas semanais para 10 . 0 material de consumo, cujo componente de maior expressão é constituído pelos itens referentes à alimentação e que era destinado, inicialmente, a um contingente de 113 pessoas (incluindo as 90 crianças), foi ampliado, na simulação, proporcionalmente ao novo número de pessoas (114). Os demais itens mantiveram-se constantes.

De todas as demais simulações relativamente à creche da Instituição no 1 , a que apresenta menor resultado são os custos simulados $B$, que resultaram num custo aluno/mês de $R \$ 420,68$ (3,5 salários mínimos), situando-se abaixo da média das mensalidades praticadas pelas entidades privadas e passando a representar quase um quarto da renda familiar média. O Gráfico 3 apre-

\section{Gráfico 3 - Comparação entre os preços praticados no mercado (Plano Piloto) e os custos simulados da educação infantil na Instituição no 1 - valores correntes de outubro de 1997 em R\$}

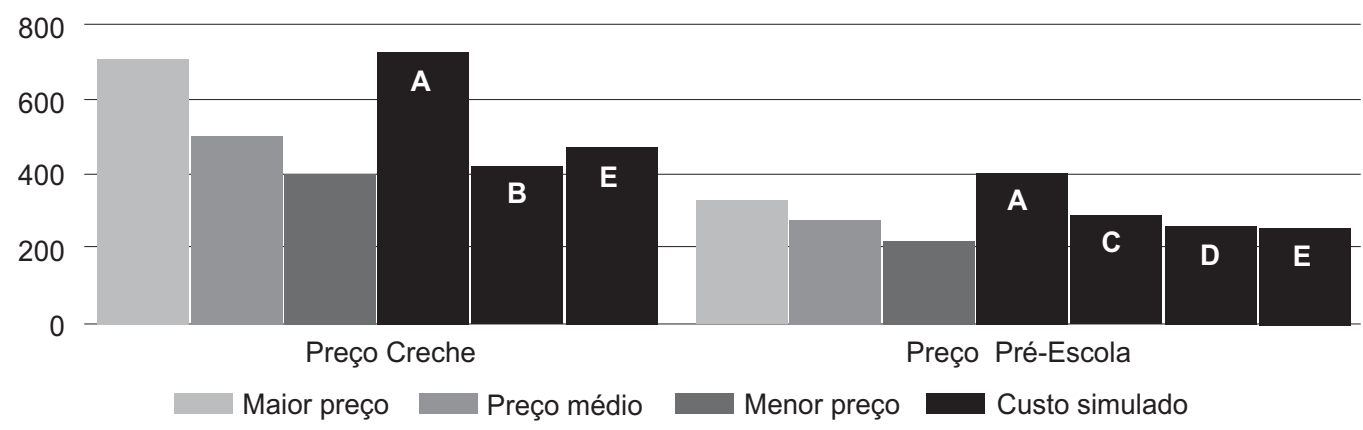

Fonte: Pesquisa de campo realizada pelo autor. 
senta a comparação entre os custos simulados e os preços das mensalidades.

Com relação à pré-escola, os menores resultados são representados pelos custos simulados E. O valor do custo aluno/mês de $R \$ 257,30$ (2,1 salários mínimos), ali apresentado, situa-se abaixo da média das mensalidades praticadas pelas entidades privadas e bem próximo do da menor mensalidade. Relacionando-o com o perfil familiar, situa-se aquém (quase metade, 55\%) da renda familiar mínima das famílias das crianças da creche. Depreende-se daí que, pelo menos para a préescola e considerando as delimitações do exercício, os recursos podem ser eficientemente combinados.

Na simulação referente à Instituição no 2 (custos simulados F), os custos aluno/mês elevam-se em aproximadamente $13 \%$, de $R \$ 144,81$ para $R \$ 164,14$. Esse custo aluno/mês, que eqüivale a 1,4 salário mínimo, representa $42,4 \%$ da renda média das famílias, considerando a média anual de $141 / 3$ salários, contra os $36,4 \%$ anteriores. Relativamente a maior renda (5,7 salários mínimos), o custo decorrente da simulação representa $24,6 \%$ (antes, esse percentual era de $21,1 \%$ ). Comparando com a menor renda $(1,8 \mathrm{sa}-$ lário mínimo), tais custos passam de $66,7 \%$ para $77,8 \%$. Este acréscimo deverá ser compensado pelo benefício da consecução de um gerenciamento de fato, o que deverá refletir-se positivamente na qualidade dos serviços.

Com relação ao mercado, os custos simulados $\mathrm{F}$ continuam abaixo dos menores preços pesquisados. Representam aproximadamente $61 \%$ do preço médio e $80 \%$ do menor preço praticado (antes, esses percentuais eram de $53,0 \%$ e $70,6 \%$, respectivamente). Como se pode observar, mesmo com a ampliação do quadro, com vistas a regularizar a distribuição do trabalho e a emprestar maior eficiência na gestão, os reflexos nos custos são tímidos. O Gráfico 4 apresenta a comparação entre os custos simulados e os preços das mensalidades, para o caso da Instituição no 2 .

\section{Conclusões}

Evidentemente, não se pretendeu aqui esgotar 0 assunto relativamente aos custos da Educação Infantil, nem tampouco quanto aos dois casos estudados ou, então, estabelecer modelo ou conclusões generalizáveis, mesmo porque, não imperou, na escolha das instituições pesquisadas, critério que as credenciasse como representativas do universo. Pretendeu-se tão-somente analisar um referencial que permita visualizar as grandezas envolvidas, bem como estabelecer comparações, servindo como instrumento para auxiliar no processo de planejamento e gestão dos recursos envolvidos nesse segmento da educação.

A maneira como foram detalhadas a metodologia e a forma de apresentação dos resultados certamente facilitarão eventuais ajustes, tanto dos elementos de cálculo como dos resultados oferecidos, de modo a adaptá-los a possíveis casos cujos custos se deseje estimar, partindo do referencial ora oferecido.

\section{Gráfico 4 - Comparação entre os preços praticados no mercado (Cidades-Satélites) e os custos simulados da educação infantil na Instituição no 2 - valores correntes de outubro de 1997 em R\$}

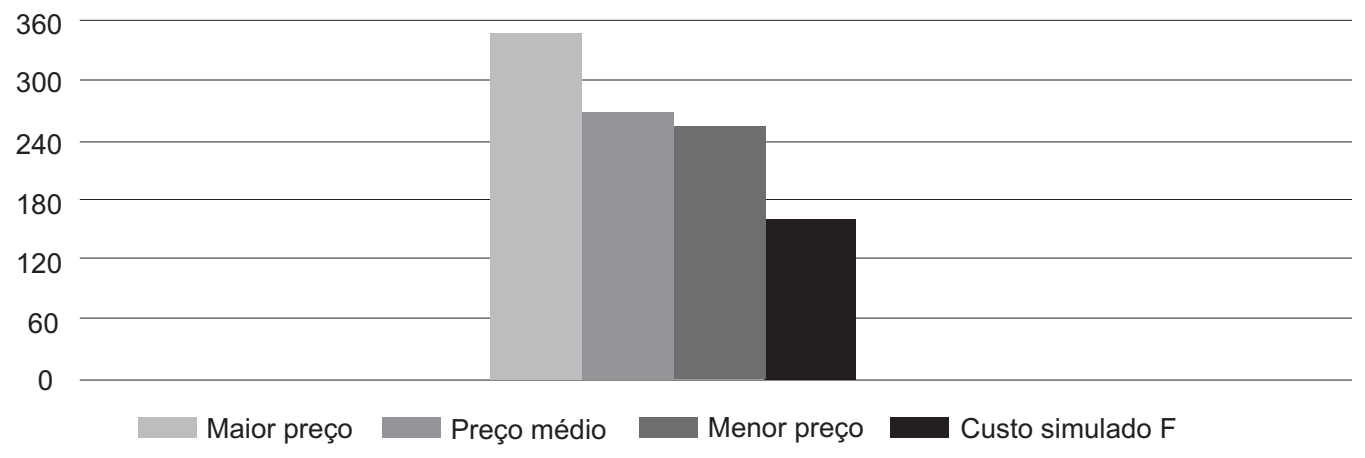

Fonte: Pesquisa de campo realizada pelo autor. 
É evidente que, no presente caso, trabalhar com a média aritmética dos resultados não seria aconselhável, pois dificilmente existiria uma instituição que preenchesse as características correspondentes a essa média. A literatura consultada desaconselha tal procedimento. No entanto, pode-se partir do resultado daquela instituição, seja a de número 1 , seja a de número 2, que mais se aproxime do caso a ser examinado e proceder aos ajustes necessários, sem perder de vista as peculiaridades de cada caso.

Em análise paralela, se utilizados os preços de mercado como referencial de eficiência, num mercado supostamente de livre concorrência, constata-se, quanto à creche da Instituição no 1, patente ineficiência no emprego dos recursos, haja vista que os custos aluno/mês superam em $70 \%$ o preço médio das mensalidades praticadas pelas entidades privadas que oferecem tais serviços. Superam também o maior preço em $20 \%$, com o agravante de que este se refere a uma entidade que inclui nutricionista de plantão, médico particular ao alcance em caso de emergência e que visita regularmente as crianças, o que não ocorre com a creche da Instituição no 1.

O sintoma da falta de eficiência no emprego dos recursos já fora observado antes, quanto à existência de ociosidade, tanto de recursos materiais como de pessoal. Há despesas de material permanente em excesso e também de material de consumo, relativamente à alimentação e higiene. Há ainda material de limpeza e conservação empregados numa área excessiva. Pelas mesmas razões, o item "Outras despesas" encontra-se igualmente "inchado", graças, sobretudo, ao consumo de energia e de água. Todos esses aspectos de ociosidade se refletem com menor intensidade na parte relativa à préescola da Instituição no 1, por funcionar em apenas um turno e também pelo fato de o excedente de recursos humanos estar ocorrendo na creche, embora, como visto, os custos da pré-escola se situem também acima do maior preço cobrado pelas entidades pesquisadas.

Quanto à Instituição no 2, embora ofereça serviços mais modestos, seu desempenho torna-se mais eficiente. Seu custo aluno/mês, como visto, representa quase a metade do menor preço cobrado pelas entidades privadas pesquisadas. No en- tanto, a falta de pessoal no segmento administrativo enseja uma aparente "economia" de mão-de-obra que se reflete favoravelmente nos custos, mas desfavoravelmente na qualidade. Esse problema, no entanto, poderia ser solucionado com a simples contratação de um gestor ou coordenador. O exercício simulatório apresenta estimativa de acréscimo de apenas 13\% nos custos aluno/mês (de R $\$ 144,81$ para $R \$ 164,14)$, permanecendo ainda abaixo do menor preço de mercado.

Com relação ao aspecto da eqüidade social, o perfil de renda das famílias da Instituição $n=1$, conforme foi demonstrado antes - exceto no caso dos segmentos de renda mais baixa, próximos da renda mínima (um salário mínimo para a creche e 3,2 para a pré-escola), não pode ser caracterizado como baixa renda, pois a média, mesmo após abatidos os $\mathrm{R} \$ 85,00$ com que as famílias contribuem, situa-se em 12,8 e 11 salários mínimos, respectivamente para creche e pré-escola, valores que ultrapassam o limite de isenção do Imposto de Renda, que é de 7,5 salários mínimos.

Já com relação à Instituição $n=2$, diferentemente da anterior, em face da inferioridade do nível de renda e de os serviços serem totalmente gratuitos para as famílias, é visível sua contribuição para a eqüidade social. A renda das famílias está na faixa de 1,8 a 5,7 salários mínimos e a média é de 3,3 salários mínimos, caracterizando-se efetivamente como de baixa renda, isenta, portanto, do imposto de renda.

Por fim, suponhamos que o governo eventualmente desejasse atender a todas as crianças do País na faixa de 0 a 3 anos, oferecendo, aos que faltam ser atendidos, creches nos moldes da Instituição no 2 admitido o pressuposto de ampliação do quadro do gestor considerado no cálculo dos custos simulados F. Obviamente, não se deve perder de vista, nesse tipo de exercício, que a demanda de atendimento a ser considerada não inclui necessariamente toda a população dessa faixa. Há crianças, por exemplo, cujas mães não trabalham fora e preferem cuidar elas próprias de seus filhos. Por isso, estimando que o número de crianças que necessitam de atendimento se situe em torno de $90 \%$ da população não atendida em 1991 com idade inferior a 4 anos, o custo anual - considerando 90 crianças por instituição - seria, com base nos custos simulados $F(R \$ 1.969,70$ alu- 
no/ano), de $\mathrm{R} \$ 251.763,10 \mathrm{mil}$, o que representa um pouco mais do mesmo valor das despesas realizadas pela União em 1996 na educação infantil e aproximadamente $5 \%$ das despesas com a educação superior e $8,4 \%$ das despesas com ensino fundamental.
Finalmente, conforme foi mostrado, pode haver atendimento público por altos custos (Instituição no-1) e pode haver por custos módicos (Instituição no 2). Se forem combinadas eficiência e qualidade, será possível alcançar os objetivos constitucionais e legais relativos à educação infantil.

\section{Referências bibliográficas}

CAMPOS, Maria Malta. As organizações não-governamentais e a educação pré-escolar. Cadernos de Pesquisa, São Paulo, n. 67. p. 17-22, nov. 1988.

CAMPOS, Maria Malta et al. Creches e pré-escolas no Brasil. 2. ed. São Paulo : Cortez; Fundação Carlos Chagas, 1995.

CASTRO, Cláudio de Moura. Ensino técnico : desempenho e custos. Rio de Janeiro: Ipea/Inpes, 1972.

. Investimento em educação no Brasil : um estudo socioeconômico de duas comunidades industriais. Rio de Janeiro : Ipea/Inpes, 1973.

CASTRO, Cláudio de Moura et al. A Educação na América Latina : estudo comparativo de custos e eficiência. Rio de Janeiro : FGV/lesae, 1980.

CASTRO, Maria Helena Guimarães de. A política de educação infantil no âmbito brasileiro. In: SIMPÓSIO NACIONAL DE EDUCAÇÃO INFANTIL. Brasília: MEC/SEF/DPE/ COEDI, 1994.

CUNHA, Luiz Antonio. Educação e desenvolvimento social no Brasil. Rio de Janeiro : Francisco Alves, 1975.

FRANCO, Hilário. Contabilidade industrial : com apêndice de Contabilidade Agrícola. 8. ed. São Paulo : Atlas, 1987.

GALLAGHER, Mark. A public choice theory of budgets : implications for education in less developed countries. Comparative Education Review, Chicago, v. 37, n. 2, p. 90-60, May, 1993.

GOMES, Candido Alberto. Os caminhos e descaminhos dos recursos financeiros em educação. Revista Brasileira de Estudos Pedagógicos, Brasília, v. 75, n. 179/180/ 181, p. 9-32, jan./dez. 1994.

GOMES, Candido Alberto, SOBRINHO, José Amaral. Educação Especial no Brasil : perfil do financiamento e das despesas. Brasília: MEC/SEESP/Unesco, 1996.

GOVERNO DO DISTRITO FEDERAL. Secretaria da Educação. Custo direto de funcionamento das escolas da rede oficial do Distrito Federal - 1985. Brasília : Secretaria de Educação, Departamento de Planejamento Educacional, 1986.

HOLANDA, Nilson. Planejamento e projetos. 2. ed. Rio de Janeiro : Apec, 1975.

KRAMER, Sonia (Coord.). Com a pré-escola nas mãos : uma alternativa curricular para a educação infantil. 6. ed. São Paulo : Ática, 1993.

LEONE, George Guerra. Custos : um enfoque administrativo. 7. ed. Rio de Janeiro: FGV, 1983. v. 1.

MARQUES, Antonio Emílio Sendim. O custo-aluno : tornando fácil um tema difícil. Universa, Brasília, v. 3, n. 2, p. 351-373, out. 1995. 
MARTINS, Eliseu, NETO, Alexandre Assaf. Administração financeira : as finanças das empresas sob condições inflacionárias. São Paulo: Atlas, 1986.

MINAS GERAIS. Secretaria de Estado da Educação. Estudo dos custos do ensino : documento 4. Belo Horizonte : Imprensa Oficial, 1978.

MISHAN, E. J. Análise de Custos-Benefícios : uma introdução informal. Rio de Janeiro : Zahar, 1976.

RIO DE JANEIRO. Prefeitura Municipal da Cidade. Custo/aluno. Rio de Janeiro : Secretaria Municipal de Educação e Cultura, [s.d.].

ROMÃO, José Eustáquio. Financiamento da educação infantil. In: SIMPÓSIO NACIONAL DE EDUCAÇÃO INFANTIL. Brasília : MEC/SEF/DPE/COEDI, 1994.

THE WORLD BANK. Human resources in Latin America and the Caribean : priorities and action. Washington, DC : The World Bank, 1993.

VAIZEY, J., CHESSWAS, L. D. The costing of education plans. [S.I.] : Unesco, 1967.

XAVIER, Antonio Carlos da R., MARQUES, Antonio Emílio Sendim. Custo direto de funcionamento das escolas públicas de $1^{\circ} \mathrm{grau}$ : aspectos metodológicos e manual de instruções. Brasília : Secretaria de Educação, 1986.

ZYMELMAN, Manuel. Financing and Efficiency in Education. Boston : Haward University, 1973.

Recebido em 25 de setembro de 1998.

Alberto Merchede, mestre em Educação pela Universidade Católica de Brasília (UCB), é professor dessa universidade.

\section{Abstract}

This article presents the results of a research that calculates the direct operational cost of two nurseries correspondingly located in the Pilot Plan of Brasilia and in a satellite city of the Federal District, one of them being partially maintained by Public Authorities and the community, and the other by a private institution (community). The article also presents the indirect costs of families, based on undetermined sample. The method used is based on the methodology for calculating the "direct operational cost of basic education schools", with the application at international level inclusive. The results are presented in terms of pupil/year and pupil/month costs, separately and corresponding to the following cost items: personnel, expendable equipment, non-expendable equipment, building, other costs and families' costs. The study compares the results among the institutions; comparing them with the pupils' parents income profile and with practiced market prices by children educational private institutions and presents, as an exercise, six simulated situations. Concluding, the author demonstrates that it is possible to associate efficiency with quality to obtain educational objectives.

Key-Words: infantile education; costs with education; quality of teaching. 